Metallophysics and Advanced Technologies

металофіз. новітні технол.

Metallofiz. Noveishie Tekhnol.

2021 , vol. 43 , No. 10 , pp. 1351-1363

https://doi.org/10.15407/mfint.43.10.135

Reprints available directly from the publisher
(C) 2021 G. V. Kurdyumov Institute for Metal Physics, National Academy of Sciences of Ukraine Published by license under

the G. V. Kurdyumov Institute for Metal PhysicsN.A.S. of Ukraine Publishers imprint. Printed in Ukraine.

PACS numbers: 61.66.Dk, 62.20.Qp, 62.25.-g, 68.55.-a, 81.15.Pq, 81.65.Kn

\title{
Effects of Current Density on Ni-P Coating Obtained by Electrodeposition
}

\author{
F. Lekmine ${ }^{*, * *}$, K. Digheche ${ }^{* * *}$, M. Naoun ${ }^{* * * *}$, \\ H. Bentemam ${ }^{* * *}$, and A. Gana \\ "Université Abbas Laghrour de Khenchela, \\ BP 1252 Route de Batna Khenchela, \\ 40004 Khenchela, Algeria \\ ** Mohamed Khider University of Biskra, \\ BP 145RP, 07000 Biskra, Algeria \\ *:Université Batna 2, \\ 53 Route de Constantine. Fésdis \\ 05078 Batna, Algeria
}

In this work, $\mathrm{Ni}-\mathrm{P}$ coatings are deposited on the steel substrate by electrodeposition from a solution containing nickel sulfate and sodium hypophosphite $\left(\mathrm{NaH}_{2} \mathrm{PO}_{2}\right)$. The effect of the current density on the morphology, phase structure, microhardness, and corrosion performance of the $\mathrm{Ni}-\mathrm{P}$ coatings are studied. Scanning electron microscopy and energy dispersive X-ray analysis and X-ray diffraction are used to study the morphological, composition and phase structure. The corrosion performance of the coatings is evaluated by weight loss, electrochemical impedance spectroscopy and Tafel polarization. Results showed that the morphology of the electrodeposited $\mathrm{Ni}-\mathrm{P}$ alloys coatings has spherical grains for all the samples, and the $\mathrm{Ni}_{3} \mathrm{P}$ phases are formed all over the microstructure of the coatings. It is observed that the phosphorus content and microhardness are dependent on the current density. The corrosion tests show that $5 \mathrm{~A} \cdot \mathrm{dm}^{-2}$ current density is the optimal value which gives the best protective coating against corrosion. It also exhibits superior microhardness originated from the higher $\mathrm{Ni}_{3} \mathrm{P}$ amount.

Key words: morphology, $\mathrm{Ni}-\mathrm{P}$ coatings, microhardness, phase structure, current densities, corrosion.

Corresponding author: Farid Lekmine

E-mail: faridtec@gmail.com

Citation: F. Lekmine, K. Digheche, M. Naoun, H. Bentemam, and A. Gana, Effects of Current Density on Ni-P Coating Obtained by Electrodeposition, Metallofiz. Noveishie Tekhnol., 43, No. 10: 1351-1363 (2021), DOI: 10.15407/mfint.43.10.1351. 
У даній роботі покриття $\mathrm{Ni}-\mathrm{P}$ наносили на сталеву підкладку електроосадженням 3 розчину, що містить сульфат нікелю та гіпофосфіт натрію $\left(\mathrm{NaH}_{2} \mathrm{PO}_{2}\right)$. Досліджено вплив густини струму на морфологію, фазову структуру, мікротвердість і корозійні характеристики покриттів $\mathrm{Ni}-\mathrm{P}$. Сканувальна електронна мікроскопія, енергодисперсійний рентгенівський аналіз та дифракція рентгенівських променів використовувалися для вивчення морфології, складу і фазової структури. Корозійні властивості покриттів оцінювали за втратою ваги та за допомогою електрохемічної імпедансної спектроскопії та поляризації Тафеля. Результати показали, що морфологія покриттів $\mathrm{Ni}-\mathrm{P}$, електроосаджених на стопи, характеризується сферичними зернами для всіх зразків, а $\mathrm{Ni}_{3} \mathrm{P}$ фази формуються по всій мікроструктурі покриттів. Помічено, що вміст фосфору і мікротвердість залежать від густини струму. Випробування на корозію показують, що густина струму $5 \mathrm{~A} \cdot$ дм $^{-2} \epsilon$ оптимальним значенням, що забезпечує найкраще захисне покриття від корозії, яке також демонструє хорошу мікротвердість, обумовлену підвищеним вмістом $\mathrm{Ni}_{3} \mathrm{P}$.

Ключові слова: морфологія, покриття $\mathrm{Ni}-\mathrm{P}$, мікротвердість, фазова структура, густина струму, корозія.

(Received April 2, 2021; in final version, August 2, 2021)

\section{INTRODUCTION}

$\mathrm{Ni}-\mathrm{P}$ coatings are widely used in aerospace, automotive and chemical industries, as well as in oil production. They are also preferably used in the electronics industry. The need to improve metals protection against corrosion motivated researchers to find new coatings or ameliorate the existing ones [1]. The preparation of coatings using electrochemical methods is attractive due to their simplicity, and also controlling bath parameters (bath composition, $\mathrm{pH}$, temperature). The physical and mechanical properties of the coatings can be modified within a certain range using the opportunity to work generally at ambient temperature, the uniform, and controllable deposition rate, the possibility to form multilayer, the ability to coat large surfaces in almost any shape and geometry, and the low cost [2-4]. Ni-P coatings can be deposited effectively on steel [5,6], aluminium alloys [7], copper [8-11]. The electrodeposition process plays a crucial role in the formation of thin films on materials, occurring through the electrochemical reduction of metal ions in the electrolytic solutions. At this point, several investigators are interested in $\mathrm{Ni}-\mathrm{P}$ coating because of their important properties such as the corrosion resistance, good solderability, high electrical conductivity, smooth surface formation and symmetry, low coefficient of friction, electrical activity and paramagnetic properties obtained by the simple electrochemically processes, and also for their shiny and smooth appearance, unlike the deposit of nickel $[7-10,12]$. Despite the complexity of this deposit, its phase dia- 
gram shows the existence of several stable states depending on the percentage of phosphorus [13]. Given that the $\mathrm{P}$ content largely determines the properties of $\mathrm{Ni}-\mathrm{P}$ coatings, important is the chemical composition of the electrodeposition bath [11]. Metallurgical properties of alloys are also dependent on percentages of phosphorus. the nip alloy with $\mathrm{p}$ content greater than $8 \%$ wt. (high phosphorus content) possesses excellent mechanical properties, such as hardness, wear resistance, and corrosion resistance $[9,11,14]$. More studies have been conducted on electroless $\mathrm{Ni}-\mathrm{P}$ nanocomposites in recent decades. $\mathrm{Ni}-\mathrm{P}-\mathrm{SiC}, \mathrm{Ni}-$ $\mathrm{P}-\mathrm{TiO}_{2}, \mathrm{Ni}-\mathrm{P}-\mathrm{Al}_{2} \mathrm{O}_{3}$, and $\mathrm{Ni}-\mathrm{P}-\mathrm{CNT}$, are successful examples that have attracted attention owing to the improved properties relative to the original $\mathrm{Ni}-\mathrm{P}$ coatings [1]. Although there are several types of research on the electro-deposition of $\mathrm{Ni}-\mathrm{P}$ alloys, there are limited studies on the effect of current density on the properties of Ni-P coatings. In the present study, the direct current (DC) electrodeposited method is used to make $\mathrm{Ni}-\mathrm{P}$ alloy coatings. The aim of this work is to investigate the effect of plating deposition current density on the $\mathrm{Ni}-\mathrm{P}$ electrodeposited coatings.

\section{EXPERIMENTAL}

\subsection{Electrodeposition of $\mathrm{Ni}-\mathrm{P}$ Coatings}

$\mathrm{Ni}-\mathrm{P}$ coatings ware deposited on steel substrates, the chemical composition and the surface morphology of the steel are given in Table 1 and

TABLE 1. Chemical composition of steel substrate.

\begin{tabular}{c|c|c|c|c|c|c|c|c|c|c|c}
\hline Element & $\mathrm{Cu}$ & $\mathrm{Mn}$ & $\mathrm{C}$ & $\mathrm{Al}$ & $\mathrm{S}$ & $\mathrm{Si}$ & $\mathrm{P}$ & $\mathrm{Nb}$ & $\mathrm{Ti}$ & $\mathrm{Mo}$ & $\mathrm{V}$ \\
\hline \% wt. & 0.16 & 1.17 & 0.19 & 0.04 & 0.07 & 0.23 & 0.007 & 0.01 & 0.01 & 0.06 & 0.01 \\
\hline
\end{tabular}

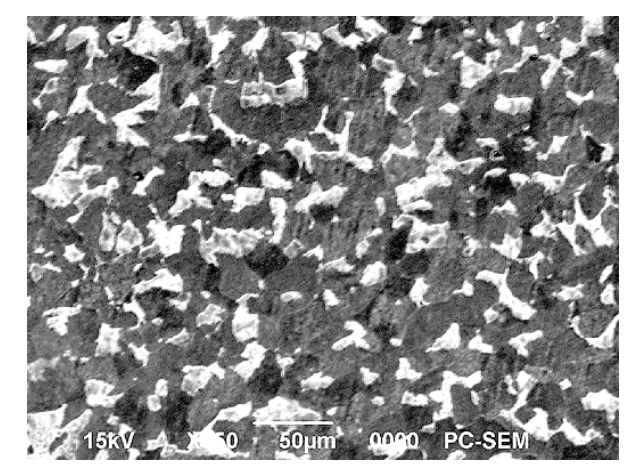

Fig. 1. SEM images of the surface of steel. 


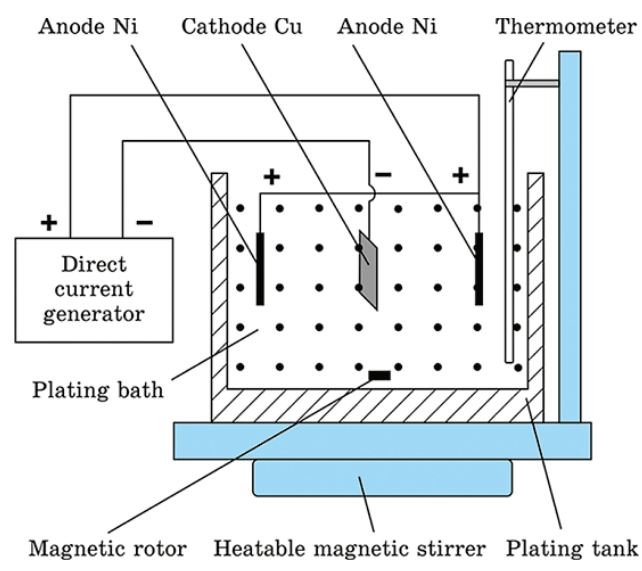

Fig. 2. Experimental setup of $\mathrm{Ni}-\mathrm{P}$ coating.

TABLE 2. Chemical composition and deposition parameters of $\mathrm{Ni}-\mathrm{P}$ coatings.

\begin{tabular}{ccc}
\hline Bath composition & Concentration & Conditions \\
\hline $\mathrm{NiSO}_{4}, 7 \mathrm{H}_{2} \mathrm{O}$ & $52 \mathrm{~g} \cdot \mathrm{L}^{-1}$ & Temperature: $75-80^{\circ} \mathrm{C}$ \\
$\mathrm{NaH}_{2} \mathrm{PO}_{2}, 2 \mathrm{H}_{2} \mathrm{O}$ & $26 \mathrm{~g} \cdot \mathrm{L}^{-1}$ & Current density: $1,9 \mathrm{~A} \cdot \mathrm{dm}^{-2}$ \\
$\mathrm{H}_{3} \mathrm{BO}_{3}$ & $24 \mathrm{~g} \cdot \mathrm{L}^{-1}$ & $\mathrm{pH}: 3$ \\
$\mathrm{NaCl}$ & $40 \mathrm{~g} \cdot \mathrm{L}^{-1}$ & Deposition time: $30 \mathrm{~min}$ \\
Saccharin & $0.01 \mathrm{~g} \cdot \mathrm{L}^{-1}$ & Stirring rate: $200 \mathrm{rpm}$ \\
\hline
\end{tabular}

Fig. 1. The substrate is mechanically polished with $\mathrm{SiC}$ abrasive paper (120 up to 1200), cleaned with acetone, rinsed with distilled water and dried; we degreased in $\left(50 \mathrm{~g} \cdot \mathrm{L}^{-1} \mathrm{Na}_{2} \mathrm{CO}_{3}\right.$ and $\left.15 \mathrm{~g} \cdot \mathrm{L}^{-1} \mathrm{NaOH}\right)$ solution, then pickled in $10 \% \mathrm{HCl}$ solution to remove oxide traces, and finally washed with distilled water. The cell contains a nickel plate $(30 \times 10 \times 2$ $\mathrm{mm}^{3}$ ) of commercial purity $(99.99 \%)$ and the steel substrate with $\left(30 \times 10 \times 5 \mathrm{~mm}^{3}\right)$, are used as anode and cathode respectively, in which the anode and cathode are kept parallel $1 \mathrm{~cm}$ apart in a conventional $200 \mathrm{ml}$ cell (Fig. 2). The composition and operating parameters for electroplating alloy coatings are shown in Table 2.

\subsection{Ni-P Coatings Characterization}

Surface morphology of the coatings and the percentage by weight of constituent elements of the coatings is characterized using scanning electron microscope FEI QUANTA 200 (SEM) and energy-dispersive Xray spectroscopy (EDX) analysis tool attached to SEM respectively, $\mathrm{X}$ ray diffractometer (XRD) (D8 Advance model) with $\mathrm{Cu} K_{\alpha}$ radiation $(1.5406 \AA)$ is used to analyse the phases structure. 
In order to test the adhesion of the $\mathrm{Ni}-\mathrm{P}$ coatings, the samples are heated for 30 minutes at $250^{\circ} \mathrm{C}$ and then immersed in water at room temperature [15].

The coatings microhardness is performed by Vickers microhardness tester (Wilson 402UD Wolpert instrument,) at a load of $100 \mathrm{~g}$ for $10 \mathrm{~s}$ taking an average of five measurements for each sample.

The corrosion phenomenon is investigated by three methods: weight loss, potentiodynamic polarization and electrochemical impedance spectroscopy (EIS). Potentiodynamic polarization measurements are conducted at ambient temperature with a potentiostat Volta lab PGP 201, a three electrodes cell, the Ni-P coating is used as working electrode (WE), a Platinum plate counter electrode (CE), and a calomel electrode $\left(\mathrm{Hg}_{2} \mathrm{Cl}_{2}\right)$ as a reference electrode $(\mathrm{RE})$. The cell capacity is 300 $\mathrm{ml}$ filled with $1 \mathrm{ml} \mathrm{HCl}$ solution. The potentiodynamic polarization

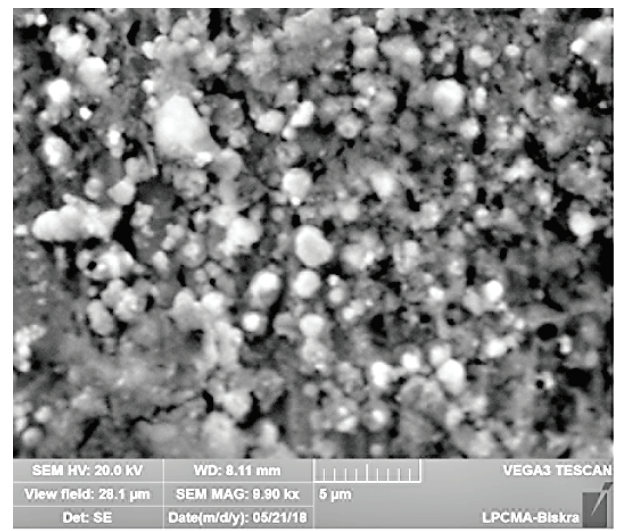

$a$

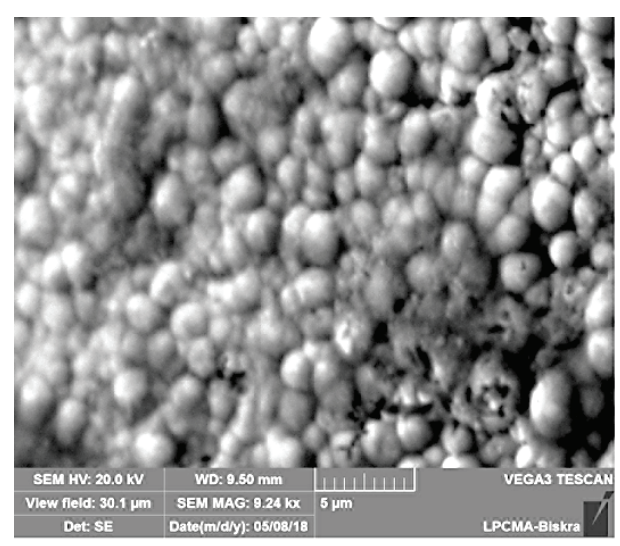

$c$

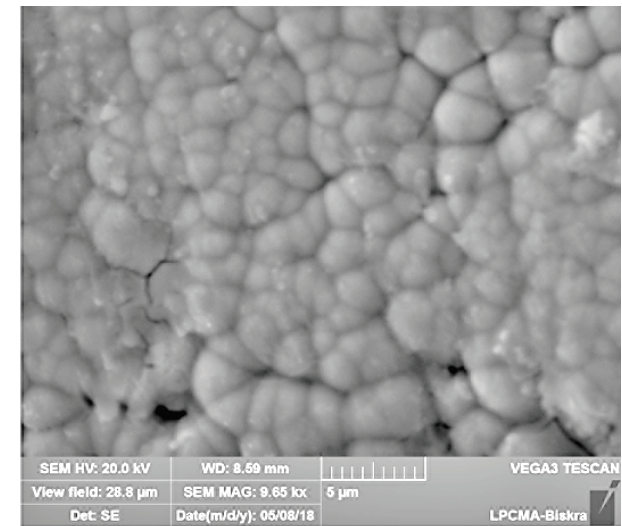

$b$

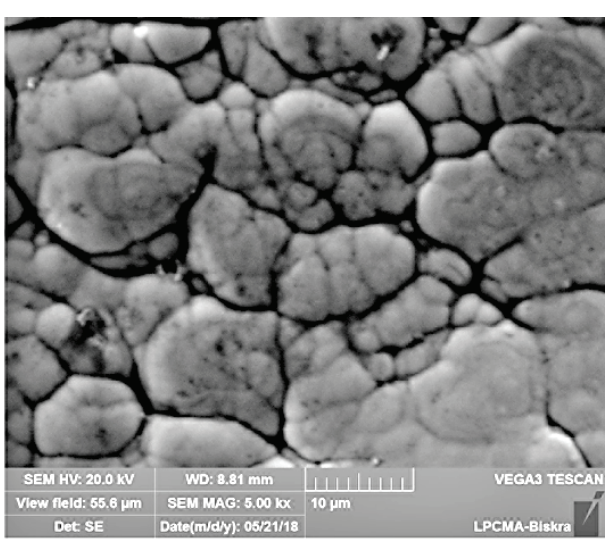

$d$

Fig. 3. SEM images of $\mathrm{Ni}-\mathrm{P}$ coatings electrodeposited at: $1 \mathrm{~A} \cdot \mathrm{dm}^{-2}(a) ; 3$ $\mathrm{A} \cdot \mathrm{dm}^{-2}(b) ; 5 \mathrm{~A} \cdot \mathrm{dm}^{-2}(c), 7 \mathrm{~A} \cdot \mathrm{dm}^{-2}(d), 9 \mathrm{~A} \cdot \mathrm{dm}^{-2}(e)$. 


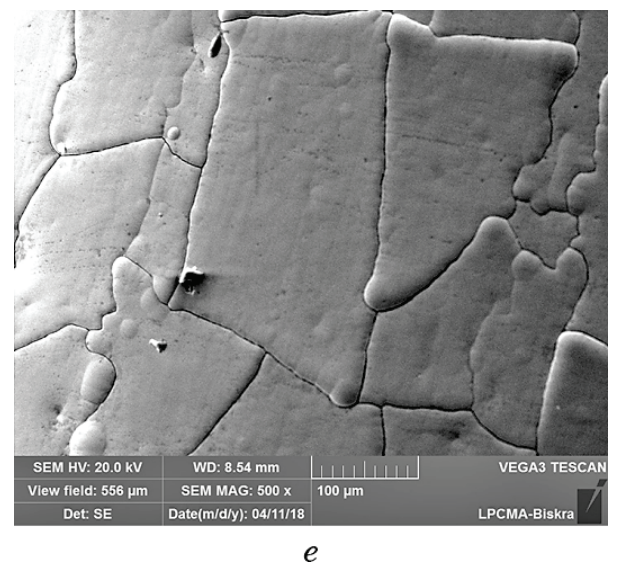

Continuation of Fig. 3.

tests are conducted at a scan rate of $20 \mathrm{mV} / \mathrm{min}$, and within a potential range from -600 up to $-200 \mathrm{mV}$. Corrosion parameters are determined using the Tafel extrapolation technique provided by Volta master 4 Software. Electrochemical impedance spectroscopy (EIS) is used to obtain Nyquist plots, within the frequency range $10^{-2}-10^{-5} \mathrm{~Hz}$.

\section{RESULTS AND DISCUSSION}

\subsection{Effects of Applied Current Density}

\subsubsection{Surface Morphology}

Figure 3 shows the surface morphology of Ni-P coatings electrodeposited at different current density.

The morphological image shows that the grains are spherical in nature for all the samples, it can be observed that there is a detachment of grains as the applied current is increased, it also can be seen the slight difference that the boundary between nodule is increasing gradually with the increasing of the amount of current density Fig. 3, $b, d, e$ ) it shows a fissured area of the $\mathrm{Ni}-\mathrm{P}$ deposit coatings. This fissured area may be attributed to the internal stresses caused by the hydrogen reaction intensification, it is noted that the morphology of these coatings is similar to those obtained by T. Mahalingam and K. Dhanapal [16, 17].

\subsubsection{Phase Structure}

The phase structure of the $\mathrm{Ni}-\mathrm{P}$ alloy coatings is observed by $\mathrm{X}$-ray diffraction instrument with $\mathrm{Cu}_{\alpha}$ radiation (1.5406 Å). Figure 4 
shows the XRD patterns of Ni-P coatings deposited with different current densities, no diffraction peaks of steel are found in all patterns indicating that substrates are completely covered, which evidence that the above mentioned cracks are superficial.

The patterns includes three peaks assigned to $\mathrm{Ni}_{3} \mathrm{P}$ and $\mathrm{Ni}$ phases at $2 \theta=50.23^{\circ}, 2 \theta=74.12^{\circ}$ and $2 \theta=44.36^{\circ}$, respectively. The crystallographic planes of the peaks are (013), (730) and (111), respectively, (Reference patterns: 98-004-3397 and 98-005-4177). At the current density $j=1 \mathrm{~A} \cdot \mathrm{dm}^{-2}$, the formation of the $\mathrm{Ni}_{3} \mathrm{P}$ intermediate phase in the Ni-P coating goes through the following stages, strong atomic interaction between $\mathrm{Ni}$ and $\mathrm{P}$, which may lead to the incorporation of $\mathrm{P}$ into the $\mathrm{Ni}$ network to form the $\mathrm{Ni}_{3} \mathrm{P}$ intermediate phase as follows.

$$
\begin{gathered}
\mathrm{Ni}^{2+}+2 \mathrm{e}^{-} \rightarrow \mathrm{Ni}_{\mathrm{ad}}, \\
\mathrm{H}_{2} \mathrm{PHO}_{3}+3 \mathrm{H}^{+}+3 \mathrm{e}^{-} \rightarrow \mathrm{P}_{\mathrm{ad}}+3 \mathrm{H}_{2} \mathrm{O}, \\
x \mathrm{Ni}_{\mathrm{ad}}+y \mathrm{P}_{\mathrm{AD}} \rightarrow \mathrm{Ni}_{x} \mathrm{P}_{y} .
\end{gathered}
$$

There is no formation about $\mathrm{Ni}_{3} \mathrm{P}$ intermediate phase in the patterns with a change of the applied current density above $5 \mathrm{~A} \cdot \mathrm{dm}^{-2}$, it can be explained that a competition between incorporation of phosphorous particles and $\mathrm{Ni}$ ions for adsorption on the cathode and the amount of adsorbed particles may vary with different current densities.

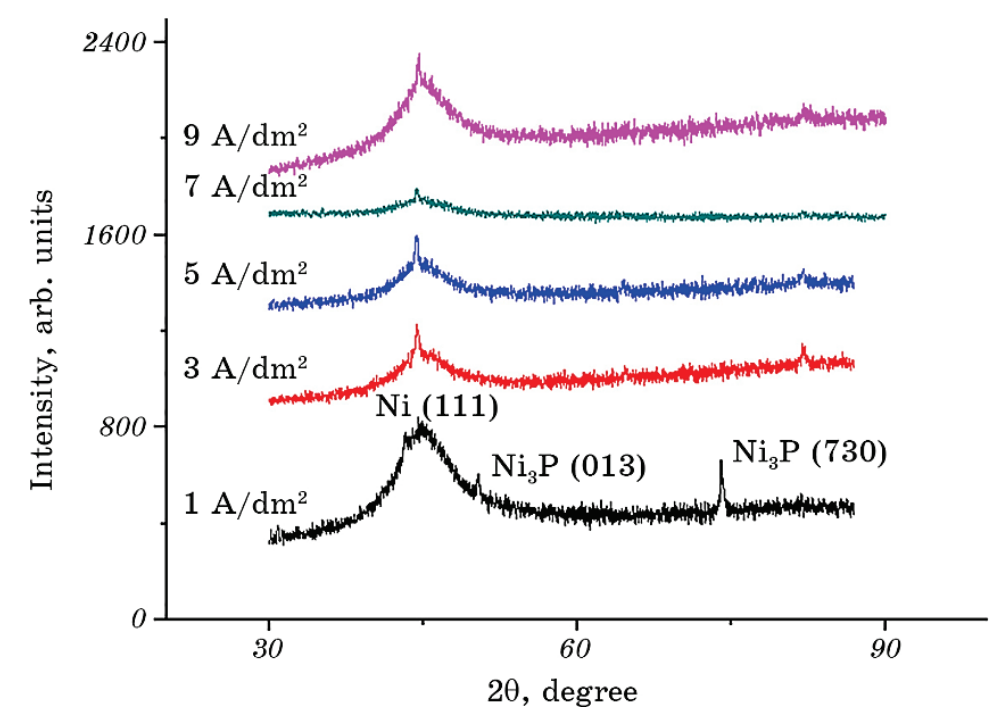

Fig. 4. XRD patterns of Ni-P alloys deposits as a function of applied current density. 


\subsubsection{Phosphorus Content of the Coating}

Figure 5 shows the results of the effect of current density on the $\mathrm{P}$ content of the Ni-P coatings from the electrodeposition samples are prepared with different current densities. The results showed that the $\mathrm{P}$ content in $\mathrm{Ni}-\mathrm{P}$ coatings decreases with increasing current density; the same results have been published about the effects of current density by Brenner and Ratzker [8]. A general trend of a decreasing phosphorous content with increasing current density is reported in the literature by many authors, although a large scatter between the data points of the different authors is noticed [7]. This behaviour is due to the rise in the movement of the Ni ions towards the cathode as a result of the variation of current density. The current density increasing causes a drop of the phosphorus content in the deposit, which may be attributed to a partial restraint of $p$ particle.

\subsubsection{Microhardness}

Figure 6 shows the Vickers microhardness of the Ni-P coatings as a function of the applied current density, the values are the average of five measurements. It is clearly seen that the coatings reached a higher microhardness at applied current density of $5 \mathrm{~A} \cdot \mathrm{dm}^{-2}$. As the microhardness of $\mathrm{Ni}-\mathrm{P}$ coatings increases the $\mathrm{P}$ content decreases, as for the coating obtained at $5 \mathrm{~A} \cdot \mathrm{dm}^{-2}$ with $\mathrm{P}$ content $(13.97 \%$ wt. P) has the highest microhardness of $350.47 H V_{\mathrm{N} 100}$. Whereas $312.65 H V_{\mathrm{N} 100}$ for the coatings at $1 \mathrm{~A} \cdot \mathrm{dm}^{-2}$ with the highest content $(18.37 \%$ wt.) $\mathrm{P}$. There are two main factors controlling the Vickers microhardness of the coatings in this study. They are as follows: (1) the amount and reg-

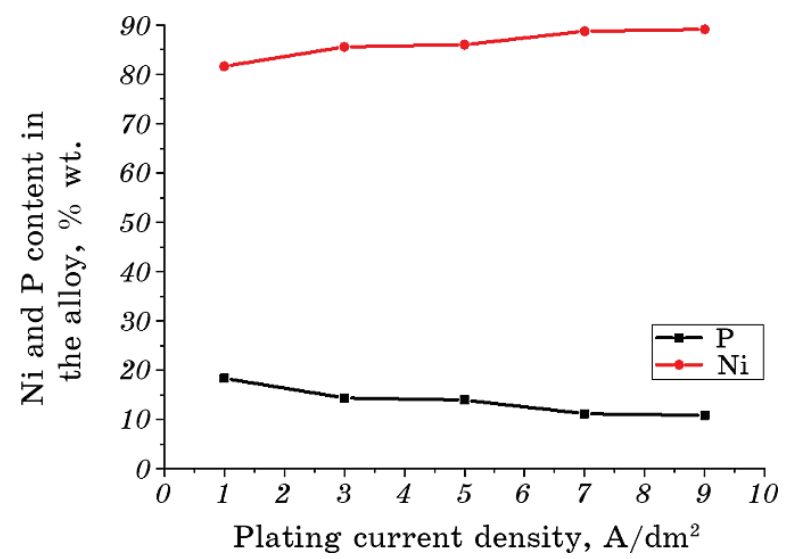

Fig. 5. Influence of applied current density on the composition of $\mathrm{Ni}-\mathrm{P}$ coatings. 


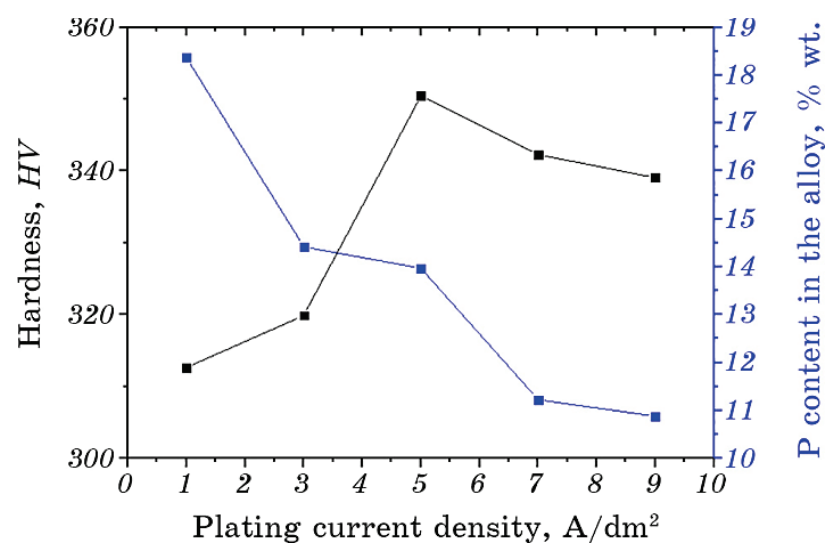

Fig. 6. Effect of the current density on hardness.

ularity of dispersion of the formed $\mathrm{Ni}_{3} \mathrm{P}$ content changing the microstructure phases [1, 18]. (2) Phosphorous content, as it has been demonstrated by Pillai et al. [7], that the mechanical properties of $\mathrm{Ni}-$ $\mathrm{P}$ based coatings shows an inverse relationship with the phosphorous content. The decrease in microhardness at $7 \mathrm{~A} \cdot \mathrm{dm}^{-2}$ and $9 \mathrm{~A} \cdot \mathrm{dm}^{-2}$ is due to the heterogeneity of the coating (cracks).

\subsubsection{Electrochemical Measurements}

\subsubsection{Weight Loss}

Corrosion tests are performed by the weight-loss method. Figure 7 shows the variation of the corrosion rate with the current density in 1

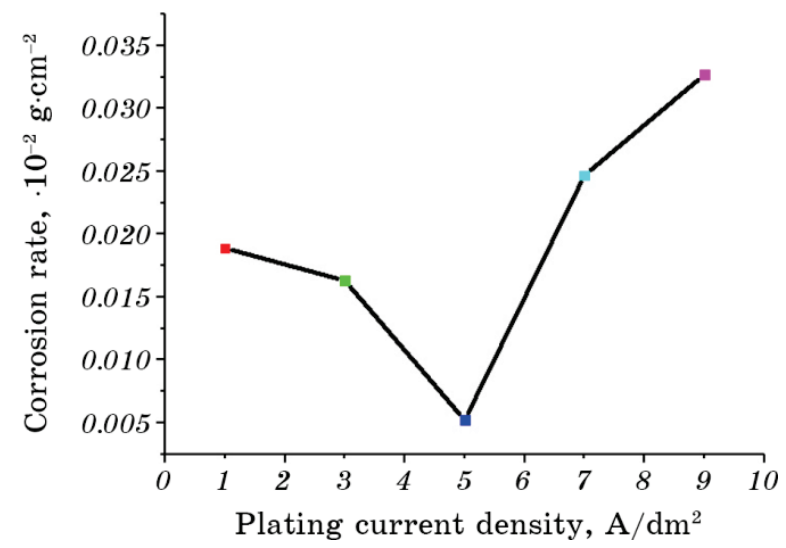

Fig. 7. Corrosion rate variation for different current densities. 
$\mathrm{ml} \mathrm{HCl}$ for 15 days immersion at room temperature. Based on the results obtained, we note that the corrosion rate decreases with the increase of current density up to $5 \mathrm{~A} \cdot \mathrm{dm}^{-2}(13.97 \%$ wt. P) (High phosphorus is known for its excellent mechanical properties, such as microhardness and corrosion resistance) and increases with increasing current density which is due to the heterogeneity and fissured coating surface. The reduction of the current density improves the corrosion resistance.

\subsubsection{Electrochemical Impedance Spectroscopy}

The Nyquist plots as well as employed electric equivalent circuit of $\mathrm{Ni}-$ $\mathrm{P}$ coatings electrodeposited at different current densities are shown in Fig. 8. The EIS derived parameters of theses samples, where $R_{\mathrm{s}}$ and $R_{\mathrm{ct}}$ correspond to electrical resistance of the electrolyte and charge transfer phenomena, respectively are shown in Table 3 , the corrosion re-

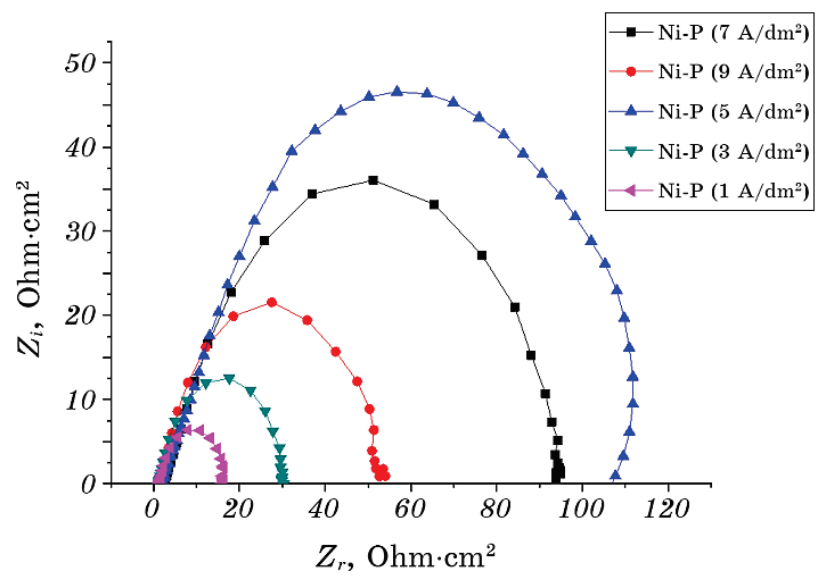

Fig. 8. Nyquist plots as well as employed electric circuit (EEC) of Ni-P coating electrodeposited at various current densities.

TABLE 3. EIS derived parameters of Ni-P coatings electrodeposited at different current densities.

\begin{tabular}{c|c|c|c}
\hline Current density, $\mathrm{A} \cdot \mathrm{dm}^{-2}$ & $R_{\mathrm{s}}, \Omega$ & $R_{\mathrm{cc}}, \Omega \cdot \mathrm{cm}^{2}$ & $C_{\mathrm{dl}}, \mu \mathrm{F} \cdot \mathrm{cm}^{-2}$ \\
\hline 1 & 2.457 & 15.76 & 780.32 \\
3 & 1.875 & 28.36 & 422.60 \\
5 & 3.694 & 114.7 & 277.2 \\
7 & 4.789 & 92.79 & 320.68 \\
9 & 2.965 & 49.91 & 402.56 \\
\hline
\end{tabular}


sistance of the coatings increases with increasing applied current density at $5 \mathrm{~A} \cdot \mathrm{dm}^{-2}$, followed by a decrease with current densities above 5 $\mathrm{A} \cdot \mathrm{dm}^{-2}$. This is due to the effect of $\mathrm{Ni}_{3} \mathrm{P}$ phase, which isolates and reduces the ions absorption and changes the corrosion mechanism from local mechanisms to various mechanisms. The $\mathrm{Ni}_{3} \mathrm{P}$ and $\mathrm{Ni}-\mathrm{P}$ matrix act as anode and cathode for this cell, respectively.

\subsubsection{Polarization Curves}

Tafel polarization curves of deposited $\mathrm{Ni}-\mathrm{P}$ coatings with different current densities are shown in Fig. 9. In addition, Table 4 represents Results of polarization measurements obtained from Tafel linear fit method. $E_{\text {corr }}$ is higher as well as a lower $I_{\text {corr }}$ indicates a corrosion resistance of the sample coated with $\mathrm{Ni}-\mathrm{P}\left(5 \mathrm{~A} \cdot \mathrm{dm}^{-2}\right)$, which means better corrosion properties of the sample. Using Tafel extrapolation, the corrosion potential $E_{\text {corr }}$ and the corrosion current density, $I_{\text {corr }}$, of the samples with the optimal $\mathrm{Ni}-\mathrm{P}$ coating are determined. The $E_{\text {corr }}$ values of the optimal Ni-P coating, is $-267.4 \mathrm{mV}$ and the $I_{\text {corr }}$ is $2.6 \mu \mathrm{m} / \mathrm{cm}^{2}$.

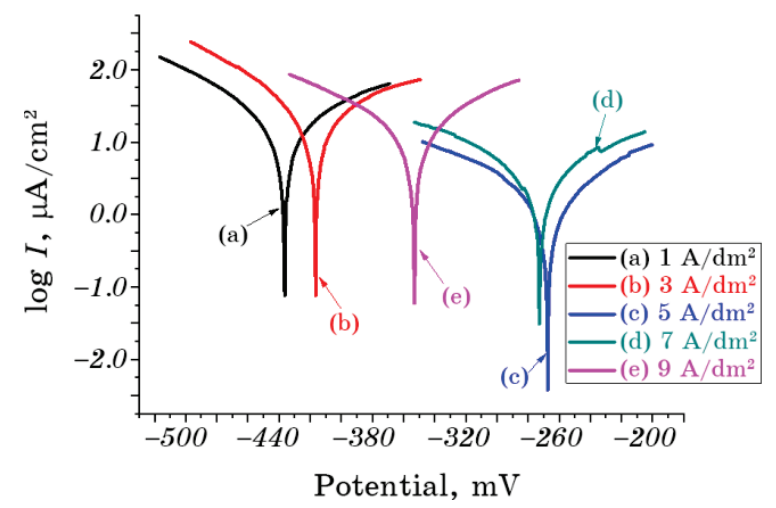

Fig. 9. Polarization curves of $\mathrm{Ni}-\mathrm{P}$ coatings electrodeposited with different current densities.

TABLE 4. Results of polarization measurements obtained from Tafel linear fit method for $\mathrm{Ni}-\mathrm{P}$ alloy coatings deposited at different current density.

\begin{tabular}{cccccc}
\hline Current density, A.dm & $E(I=0), \mathrm{mV}$ & $R_{\mathrm{p}}, \Omega \cdot \mathrm{cm}^{2}$ & $I_{\text {corr }}, \mu \mathrm{A} / \mathrm{cm}^{2}$ & $\tau, \mu \mathrm{m} / \mathrm{y}$ \\
\hline 1 & -436.5 & 934.98 & 20.1053 & 235.1 \\
3 & -416.5 & 668.83 & 26.2974 & 307.5 \\
5 & -267.4 & $9.71 \cdot 10^{3}$ & 2.0636 & 24.13 \\
7 & -272.5 & $4.06 \cdot 10^{3}$ & 3.8793 & 45.37 \\
9 & -353 & $1.03 \cdot 10^{3}$ & 14.0098 & 163.8 \\
\hline
\end{tabular}


In general, an amorphous $\mathrm{Ni}-\mathrm{P}$ alloy coating has a better corrosion resistance than the other coatings. The increased corrosion resistance of the $\mathrm{Ni}-\mathrm{P}$ coating is due to the interaction of phosphorus with the acidic medium to form the hypophosphite anions $\left(\mathrm{H}_{2} \mathrm{PO}^{-2}\right)$, which a barrier between the alloys and the electrolytes [19]. The results obtained from the weight loss method and the Tafel curves appear to be similar to the results from EIS.

\section{CONCLUSION}

In the present work, the $\mathrm{Ni}-\mathrm{P}$ coatings are prepared by electrodeposition from different currents density, the effects of applied current density on the morphology, phase structure, microhardness, and corrosion performance are studied. The most important results can be drawn as:

- the thermal shock test reveals that the deposition of $\mathrm{Ni}-\mathrm{P}$ has a good adhesion to the steel substrate;

- the coating morphology is characterized by spherical grains in all samples. It can be seen that the boundary between nodules increases gradually with increasing current density;

- based on the corrosion performance and the microhardness test, the current density of $5 \mathrm{~A} \cdot \mathrm{dm}^{-2}$ leads to the superior mechanical and corrosion properties. In general, the $\mathrm{Ni}_{3} \mathrm{P}$ phase is responsible for this improvement.

\section{REFERENCES}

1. E. M. Fayyad, A. M. Abdullah, M. K. Hassan, A. M. Mohamed, G. Jarjoura, and $Z$. Farhat, Emergent Materials, 1: 3 (2018).

2. J. Sudagar, J. Lian, and W. Sha, J.Alloys Compd.,571: 183 (2013).

3. B. D. Falola and I. I. Suni, Current Opinion in Solid State and Materials Science, 19: 77 (2015).

4. N. Ait Ahmed, M. Eyraud, H. Hammache, F. Vacandio, S. Sam, N. Gabouze, P. Knauth, K. Pelzer, and T. Djenizian, Electrochimica Acta, 94: 238 (2013).

5. K. Dhanapal, V. Narayanan, and A. Stephen, Mater. Chem. Phys., 166: 153 (2015).

6. M. M. V. Parente, O. R. Mattos, S. L. Diaz, P. Limaneto, and F. J. Fabrimiranda, J.Appl. Electrochem., 31: 677 (2001).

7. A. M. Pillai, A. Rajendra, and A. K. Sharma, J.Coat. Technol. Res., 9: 785 (2012).

8. Y. E. Sknar, O. O. Savchuk, and I.V. Sknar, Appl. Surf. Sci., 423: 340 (2017).

9. A. R. Madram, H. Pourfarzad, and H. R. Zare, Electrochimica Acta, 85: 263 (2012).

10. L. Chang, C.-H. Chen, and H. Fang, J. Electrochem. Society, 155: D57 (2008).

11. A. Bahramian, M. Eyraud, F. Vacandio, and P. Knauth, Surf. Coat. Technol., 345: 40 (2018). 
12. M. S. Nur Ariffah, M. S. Nurulakmal, A. S. Anasyida, and E. K. Shiu, Mater. Sci. Forum, 819: 97 (2015).

13. H. Okamoto, J. Phase Equilibria and Diffusion, 31: 207 (2010).

14. A. Bai, P-Y. Chuang, and C-C. Hu, Mater. Chem. Phys., 82: 93 (2003).

15. F. Lekmine, H. Ben Temam, M. Naoun, and M. Hadjadj, Journal of Nano- and Electronic Physics, 12: 01001 (2020).

16. T. Mahalingam, M. Raja, S. Thanikaikarasan, C. Sanjeeviraja, S. Velumani, H. Moon, and Y. D. Kim, Materials Characterization, 58: 800 (2007).

17. K. Dhanapal, V. Narayanan, and A. Stephen, Mater. Chem. Phys., 166: 153 (2015).

18. M. Czagany and P. Baumli, J. Mining Metallurgy, Section B: Metallurgy, 53: 327 (2017).

19. R. B. Diegle, N. R. Sorensen, C. R. Clayton, M. A. Helfand, and Y. C. Yu, Journal Electrochemical Society, 135, No. 5: 1085 (1988). 